\title{
Building internationally literate communities
}

\author{
Katie Day \\ Teacher-Librarian, United World College South-East Asia - East campus (Singapore) \\ 10 Ang Mo Kio Street 54 Singapore 569184 Email katie.appleton.day@ gmail.com \\ Barbara Philip - Teacher-Librarian, Tanglin Trust School (Singapore) \\ 95 Portsdown Rd Singapore 139299 Email barbara.philip@ tts.edu.sg
}

\begin{abstract}
How can we as librarians bring children and books from a variety of cultures and backgrounds together to create a more internationally literate community?

This workshop addresses that question with a discussion of what it means to be internationally literate as well as internationally-minded, followed by an outline of some evaluation criteria useful in selecting international children's literature. Examples will be offered of what a school library network can do to promote wider reading of literature from around the world.
\end{abstract}

All supporting materials, including booklists, for this workshop can be found online (after 30/09/10) at Kids Global Read website.

\section{Our personal and professional journeys}

Katie Day is an American who has lived overseas for 24 years. She worked as a school librarian in Thailand before arriving in Singapore in 2005. Barb Philip also arrived in Singapore in 2005. Singapore was her first overseas teaching position, having been born in New Zealand and qualifying and working as a librarian in Australia.

Katie and Barb met at the graduation ceremony for Charles Sturt University in Singapore in 2005. Both work as teacher-librarians in large, well-established, non-profit international schools in Singapore and were key organisers of the inaugural Hands On Literacy Conference in 2008. Inspired by the Panda Awards in China and the Sakura Medal in Japan (both developed by international school library networks), Katie conceived the idea of a Singaporean Children's Choice Award (Red Dot Awards), and Barb established a national Readers Cup Competition for Singapore. Both events were successfully held in the 2009-2010 school year. Barb and Katie were also behind the formalisation of the ISLN (International School Library Network - Singapore) in 2009, and Barb now serves as the president and Katie as the secretary.

The aim of the Red Dot Awards is to promote books from around the world, create cross-cultural understanding, and increase the enjoyment of reading. Teacher-librarians recommend recent books, including ones related to Singapore and to our schools' nominal affiliations (British, American, Canadian, Australian, French, German, and non-nation-specific international), and a short-list of 8 books in each of 4 reading levels is chosen. These books are promoted online and in schools from October to March, at which point voting takes place and the winners in each category are announced. The Readers Cup event, based on a selection of the shortlists, occurs in May.

This workshop is an outgrowth of our work on the Red Dot Awards and our ongoing efforts to develop initiatives that will increase the international literacy of our reading communities.

\section{Internationally literate readers}

Our education cannot be complete until we have had conversations with every continent and every civilization." -- Theodore Zeldin

International-mindedness is a concept central to curricula such as the International Baccalaureate (PYP, MYP, DP) programmes, e.g. read the January 2008 online issue of IB World which focuses on its definition and importance, and explore the IBO Sharing our Humanity community theme web page. As the article "Beyond Food, Festivals, and Flags" (Skelton et al, 2002) points out, international-mindedness goes beyond

(C) 2010 IASL, SLAQ and therein by the authors. Diversity Challenge Resilience: School Libraries in Action Proceedings of the $12^{\text {th }}$ Biennial School Library Association of Queensland, the $39^{\text {th }}$ International Association of School Librarianship Annual Conference incorporating the $14^{\text {th }}$ International Forum on Research in School Librarianship, Brisbane QLD Australia, 27 September - 1 October 2010 . 
a focus on food, festivals, flags, famous people, and fashion, and ideally promotes knowledge and understanding beyond one's nationality, along with an awareness and understanding of the independence and interdependence of people and countries and their similarities and differences. There is a large body of scholarship exploring this concept in relation to education which is revealed in a search for "internationalmindedness", "internationalism", or "intercultural literacy", a term promoted by Heyward (2002).

Being internationally literate can be defined as the ability to 'read' other cultures, whether in person or via a text.

Those working in national curriculum schools within a home country might assume becoming internationally literate is easier in an international school situated in a foreign country, yet the experience of living overseas is no guarantee that people will break out of their mental cul-de-sacs.

International schools in Singapore, which by law, local citizens cannot attend without special permission, represent a diverse mix of nationalities; however, by default many students tend to read within their own cultural boundaries, and teachers often seem most comfortable promoting literature from their home cultures.

Having said that, many "third culture kids" (Pollock \& Van Reken, 2001) in our international schools have benefited from a cosmopolitan exposure to multiple cultures (and multiple school library collections) and these students can be a valuable source of book recommendations for the librarian.

Just as it takes time and exposure to a quantity of texts to become a fluent reader, so it takes broad and varied reading over time to develop internationally literate readers.

The Nigerian novelist Chimamanda Adichie argues in her 2009 TED (Technology Entertainment and Design) talk "The danger of the single story" that one type of narrative about a time or place, especially when told over and over again, creates a stereotype - and that children are particularly vulnerable to this literary trap. She points out that the problem with stereotypes is not that they are untrue, but that they are incomplete. Children need a balance of stories, not just in terms of many cultures and countries, but also about any one culture or country.

Becoming internationally literate is important not only for students' personal development, but also for the planet.

In a recent book, The Empathetic Civilization, Jeremy Rifkin (2010), a well-known economist and activist, argues that, due to the current economic and environmental interconnectedness of the world, we need to expand our sense of belonging from the nation-state to a global identification and empathy, a mental shift that may be critical to the survival of our species and the biosphere. A summary of a speech he made at the Royal Society for the Arts has been illustrated and posted on the internet; we recommend you take the time to watch it, if not to read his book.

Getting children to read more books which expand their sense of the connectedness of the human race is a small but important step towards such an empathetic civilisation.

After World War Two, a German woman named Jella Lepman had a similar idea, envisioning children's books as bridges to peace and understanding. She believed that if children came to understand about other cultures they would be less likely to support wars in the future. IBBY (The International Board on Books for Young People) was the result, and it remains a valuable source of information about children's literature within different countries (though not necessarily in English) through its lists of honor books and Hans Christian Andersen Medal winners.

Providing students with literature in languages other than English is highly desirable, but is not the focus of this workshop; we are looking children's books in English, whether as translations or original texts. (For an

(C) 2010 IASL, SLAQ and therein by the authors. Diversity Challenge Resilience: School Libraries in Action Proceedings of the $12^{\text {th }}$ Biennial School Library Association of Queensland, the $39^{\text {th }}$ International Association of School Librarianship Annual Conference incorporating the $14^{\text {th }}$ International Forum on Research in School Librarianship, Brisbane QLD Australia, 27 September - 1 October 2010 . 
interesting overview of the past and future of English, see Robert McCrum's Globish: How English conquered the world: a guns, germs, and steel argument based on the power of the word (2010).)

\section{Critically evaluating books to support an internationally literate community}

As teacher-librarians, we regularly attempt to critically evaluate the resources that we add to our collections, e.g., their relevance to the topic, audience suitability, accessibility and authority. These critical literacies become particularly important when reading literature from around the world.

We have identified three major issues for all readers to consider when evaluating authors and titles for an international audience.

First, a word about the various adjectives that could be applied to books.

- multicultural literature -- usually refers to representations of or interactions between cultures within a nation-state, intended for readers in that nation-state; think immigration / melting pot / assimilation / citizenship;

- intercultural literature -- refers to books dealing with cultural boundaries or interactions between people from different countries, outside an immigration context;

- trans-cultural literature -- used in reference to the reader -- where the cultures portrayed are outside the reader's nation-state -- may be written by an author within the reader's nation-state expressly for the purpose of introducing new cultures -- or may be written by an author from within the culture being portrayed or an author from another culture; (Pratt \& Beaty, 1999)

- cross-cultural literature -- refers to books that include references to many cultures or nation-states; intended for an international audience or to promote international-mindedness;

In the context of this workshop, we are looking for trans-cultural literature -- from the viewpoint of our library patrons. For our readers in Singapore, this could include multicultural novels from a country like Australia, e.g. Looking for Alibrandi, or the US, e.g. A step from Heaven, as well as intercultural narrative nonfiction, e.g. The London jungle book, or multinational nonfiction, e.g. Hungry planet.

\section{A. Relevance / Appeal to the reader.}

Every school is different and books must be judged on their relevance to the library's clientele, curriculum, and location.

Books that explain the local culture are important for our international school students, all of whom are foreign nationals. The home culture of our students (which is not necessarily reflected by what passport they carry) is another consideration. If we have Indian children in our school, are we aware of which part of India they're from or what strand of the Indian diasporas their families belong to? As international schools, we also strive to collect literature that reflects the experience of 'third culture kids' living and traveling overseas, e.g. Close encounters of a third world kind by Jennifer Stewart and Bloomability by Sharon Creech, and children with parents from two different cultures, e.g. The Wakame gatherers.

Lastly, is the book appealing to the reader? A phenomenon we are seeing more of in Singapore is selfpublishing. Whilst some self-published books are fine, many lack editing and are of poor quality. Students used to polished picture books may not respond to low-cost publications.

\section{B. Cultural content / Accessibility to the reader}

Accessibility includes a consideration of age and reading level appropriateness and in our booklists (for the Red Dot awards and for this workshop), we use the following categories:

- Picture Book (may fit into any of the following divisions)

(C) 2010 IASL, SLAQ and therein by the authors. Diversity Challenge Resilience: School Libraries in Action Proceedings of the $12^{\text {th }}$ Biennial School Library Association of Queensland, the $39^{\text {th }}$ International Association of School Librarianship Annual Conference incorporating the $14^{\text {th }}$ International Forum on Research in School Librarianship, Brisbane QLD Australia, 27 September - 1 October 2010 . 
- Junior (where Captain underpants and Geronimo Stilton are the assumed reading level and readers are usually $8-10$ years old)

- Middle (where Inkheart and The lightning thief are the assumed reading level and readers are usually 9-13 years old)

- Senior (where Twilight and The book thief are the assumed reading level and readers are usually above 12 years old)

The age of the protagonist cannot be taken as the age of the intended reader, even if the reading level is appropriate. While the purpose of using literature to expose children to cultures other than their own is to encourage empathetic connectivity, some stories can be quite confronting and the cultural differences may be simply too distressing (if not for the young reader, in our situation, for the parents monitoring their child's reading!), e.g. consider Little soldier, I am Nujood, age 10 and divorced, Iqbal, and Diego, run. Contemporary fiction and biographies are preferable in terms of cultural content; non-fiction, including traditional stories, provides excellent background, but fail to provide the personal perspective.

However, knowledge gaps can be a major problem. A book published in one country meant for a local child may assume cultural knowledge that can render the book unintelligible to a child in another country - e.g. the situation of a book being 'too American' or 'too Australian'. The diary of Amos Lee has been a bestseller in Singapore, but will the use of colloquialisms and a smattering of Singlish enable that appeal to carry over outside of Singapore? This often requires librarians to pre-read books with an eye to the international stance or stamina of their patrons.

Some gaps are manageable and the reader can be encouraged to handle them as they would any reading gap (use context clues, make an assumption, ask someone, look it up). Sometimes books have glossaries (Wanting Mor, published in Australia as Jameela - by Rukhsana Khan or Possum magic by Mem Fox when published in the States), which helps as long as the reader knows it's there, instead of discovering it later.

Sports novels and assumed knowledge can be particularly troublesome. While football is popular around the world, children in the US need to mentally translate that to "soccer" and add the word "American" in front of football for the other game. Baseball and cricket are not universally familiar sports, yet in some cultures they are overwhelming popular.

Biographies can also be highly nationalistic. Many national heroes are historical figures unknown to the average child outside that country. Who did invent the light bulb? Books from the UK will highlight Joseph Swan, while Americans will say Thomas Edison.

Historical fiction can be problematic for the same reason, either too nationalistic or requiring too much background knowledge.

The style of English can be another cultural divide. For example, City stories is a book for middle readers. The content is age appropriate, but the overly careful use of English, common in South-Asia, makes it unappealing to the age group it is written for amongst native English speakers. Translations that don't read smoothly to the ear of the reader can be a similar stumbling block.

\section{Cultural accuracy / Authority / Authenticity / Currency}

Defining the culture portrayed in the book should be straightforward, but in the age of global citizenship there are often gray areas. Can a book about Chinese in the USA adequately represent Chinese culture, or is this book describing a completely separate culture (see The case of the lion dance)?

Is the expatriate point of view relevant and representative? If so, of what culture? For example Home from home . Are multiple cultures successfully represented in the work as in The Wakame gatherers?

(C) 2010 IASL, SLAQ and therein by the authors. Diversity Challenge Resilience: School Libraries in Action Proceedings of the $12^{\text {th }}$ Biennial School Library Association of Queensland, the $39^{\text {th }}$ International Association of School Librarianship Annual Conference incorporating the $14^{\text {th }}$ International Forum on Research in School Librarianship, Brisbane QLD Australia, 27 September - 1 October 2010. 
Does the work reflect a current situation or how people continue to live today? Or does it provide good background information explaining why things are as they are today, even though they may have changed? These criteria may exclude some wonderful novels set in WWII, simply because the subject of war, rather than lifestyle, is the more predominant subject.

In selecting literature about Asia, should we privilege Asian authors? Can an author from another culture write an authentic book about a culture? Frederick Lipp's books about Cambodia seem perfect for junior readers, even though he is an older American man who had not yet visited Cambodia at the time he wrote his first book, The caged birds of Phnom Penh.

Does the voice sound "real'? Can someone who, although born in a country, has lived abroad for most of their lives still write in an authentic voice? (See Shamini Flint's Ten and Rukhsana Khan's Wanting Mor published as Jameela in Australia).

Translations may also be problematic. Does the translation tell the story as the author intended?

This is where the benefits of networks -- professional and personal -- kick in. If we have questions about the authenticity or currency of a cultural representation, the fastest way to get information to support your decision is to ask people in those countries, whether via listservs (OZTL for Australia, LM_NET for the US, SLN for the UK, etc.) or through tools like Twitter.

\section{Conclusion}

In summary, the best way to build internationally literate communities is to work on becoming more internationally literate ourselves, individually and as networks, then spreading the resources and opportunities to read more widely to our students, teachers, and parents.

\section{Three key learnings:}

- To define and understand what an internationally literate community is.

- To provide strategies and resources to assist teachers and teacher-librarians in the development of internationally literate communities.

- To continue and encourage the dialogue about internationally literate communities and foster their development through networking.

\section{References}

Adichie, Chimamanda. (July 2009). Chimamanda Adichie: The danger of a single story. TED ideas worth spreading. Technology Entertainment and Design (TED). Retrieved June 5, 2010, from http://www.ted.com/index.php/talks/chimamanda_adichie_the_danger_of_a_single_story.html

City stories: Tales from here and there. Indiaclub.com. (2008) Retrieved June 5, 2010, from http://www.indiaclub.com/shop/SearchResults.asp?ProdStock=26302

Day, Katie and Philip, Barbara. (2010) Kids Global Read. Retrieved June 5, 2010, from http://sites.google.com/site/kidsglobalread/

Flint, Shamini. Young Readers. (2008) Shamini Flint. Retrieved June 5, 2010, from http://www.shaminiflint.com/books-youngreaders.html

Foo, Adeline. (2010) The diary of Amos Lee - I sit, I write, I flush. Pixie Books. Retrieved June 5, 2010, from http://www.amoslee.com.sg/home.html

Google Books. Google, 2010. Retrieved June 5, 2010, from http://books.google.com.sg/books

(C) 2010 IASL, SLAQ and therein by the authors. Diversity Challenge Resilience: School Libraries in Action Proceedings of the $12^{\text {th }}$ Biennial School Library Association of Queensland, the $39^{\text {th }}$ International Association of School Librarianship Annual Conference incorporating the $14^{\text {th }}$ International Forum on Research in School Librarianship, Brisbane QLD Australia, 27 September - 1 October 2010 . 
Heyward, M. (2002). From international to intercultural: redefining the International School for a globalised world. Journal of Research in International Education 1.9, 9-32.

International Baccalaureate Organization. (2010). IB Community Theme: Sharing our humanity. ibo.org. International Baccalaureate Organization. Retrieved June 5, 2010, from http://communitytheme.ibo.org/

“IB World - January 2008.” IB World Magazine Jan. 2008. Retrieved June 5, 2010, from http://www.ibo.org/ibworld/jan2008/index.cfm.

The International Board on Books for Young People (IBBY). (2010). Welcome to IBBY. IBBY. The International Board on Books for Young People. 28 May 2010. Retrieved June 5, 2010, from http://www.ibby.org/

International School Libraries Network (Singapore). (2010). Hands on literacy in the 21 st century classroon and library. International School Libraries Network (Singapore). Retrieved June 5, 2010, from http://www.handsonlit.com/

International School Libraries Network (Singapore) - ISLN. (2010). ISLN, June 2010. Retrieved June 5, 2010, from http://silcsing.wikispaces.com/

Red Dot Children's Choice Book Awards. (2010). Red Dot Book Awards 2009-2010. International School Libraries (ISLN) Singapore, May 2010. Retrieved June 5, 2010, from http://www.reddotawards.com/

Lipp, Frederick. (2007). Fred's books. Kids Go Global. Retrieved June 5, 2010, http://www.fredericklipp.com/books.php

McCrum, Robert. Globish: how English conquered the world: a guns, germs, and steel argument based on the power of the word. Canada: Doubleday, 2010.

Picture Books - Home from Home. (2006). mccmcreations.com. Retrieved June 5, 2010, from http://www.mccmcreations.com/books/picture\%20books/home\%20from\%20home/main.htm

Pollock, David and Van Reken, Ruth. (2001). Third culture kids: the experience of growing up among worlds. London: Nicholas Brealey Publishing.

Pratt, Linda, and Beaty, Janice J. (1999). Transcultural children's literature. Upper Saddle River, NJ: Prentice-Hall.

Rifkin, Jeremy. (2010). The empathic civilization: the race to global consciousness in a world in crisis. Cambridge, UK: Polity Press.

RSA Animate - the empathic civilisation. You Tube. (2010). Royal Society for the encouragement of Arts, Manufactures and Commerce, 6 May 2010. Retrieved June 5, 2010, from $\mathrm{http}: / / \mathrm{www}$. youtube.com/watch?v=17AWnfFRc7g\&feature=player_embedded

Skelton, Martin, et al. (2002). Beyond food, festivals, and flags. Educational leadership: the world in the classroom 60.2, 52-55. Retrieved May 5, 2010, from

http://www.ascd.org/ASCD/pdf/journals/ed_lead/el200210_skelton.pdf

Tan, Teri. (2009). Children's book publishing in Asia: developing originals and translating go hand-in-hand. Publishers Weekly (Mar. 2009). Retrieved May 29, 2010, from http://www.publishersweekly.com/pw/bytopic/childrens/childrens-book-news/article/10035-children-e2-80-99s-book-publishing-in-asia-.html

(C) 2010 IASL, SLAQ and therein by the authors. Diversity Challenge Resilience: School Libraries in Action Proceedings of the $12^{\text {th }}$ Biennial School Library Association of Queensland, the $39^{\text {th }}$ International Association of School Librarianship Annual Conference incorporating the $14^{\text {th }}$ International Forum on Research in School Librarianship, Brisbane QLD Australia, 27 September - 1 October 2010. 